\title{
Gitmo’s Folly II: Torture, Trials, and Tribulations of US Detention Policy in the Wake of 9/11
}

\author{
Samuel B. Hoff \\ Delaware State University, Delaware, USA
}

\begin{abstract}
Tapping declassified US Senate and Central Intelligence Agency reports, United Nations studies, and other primary sources, this study investigates the etiology, policies, and consequences of US detention policy as a part of the War on Terror. The record of the last two presidential administrations in dealing with detainees at Guantanamo Bay Naval Base in Cuba (GITMO) and elsewhere is examined and the legal rationale for the tactics used on those in captivity is scrutinized. The study reveals that although certain features of detention policy changed from the George W. Bush administration to the Barack Obama presidency, others remained the same. The benefits of information acquired from detainees is weighed and detention policy itself is evaluated according to fundamental
\end{abstract} American values.

Keywords: 9/11, Guantanamo Bay Naval Base in Cuba (GITMO), torture, detainees

\section{Introduction}

In the 1998 movie, The Siege, one of the characters bemoans the lack of respect for legal authority by stating that "these people, they don't give a shit about your laws". For the sake of this study, the question is whether the target of that observation is terrorists or the last two presidential administrations. The object of the research is to present a balanced analysis of the background and context for actions taken by the latter president following the heinous multiple attacks against the United States on September 11, 2001 together with the response to them. More specifically, the paper examines the detention policy put in place by the George W. Bush and Barack Obama administrations at Guantanamo Bay Naval Base in Cuba (GITMO) and elsewhere, relays criticism of the treatment of enemy combatants, reviews court cases which centered around detention policy, and offers an extended commentary of the effectiveness of that policy and of the Bush and Obama record in fighting terrorism. The importance of this topic continues to reverberate in American politics. While President Barack Obama quickly issued an executive order forbidding torture as a method of interrogation at the outset of his presidency, his promise to close the prison facility at GITMO has gone unfulfilled. Further, the recently-released Senate Select Intelligence Committee's report about CIA tactics in dealing with enemy combatants raises disturbing moral and legal questions. Finally, the renewal of violence in Iraq and the growing threat of ISIS increase the likelihood of direct confrontation between American and enemy forces, thereby keeping detention policy in the forefront of the strategy to confront international terrorism.

Samuel B. Hoff, Ph.D., Department of History, Political Science, and Philosophy, Delaware State University. 


\section{Background}

The decade of the 1990s witnessed wars fought in many forms. For instance, there was the highly successfully Gulf War in 1991, whereby the US and an international coalition forced Iraq to withdraw from its invasion and occupation of Kuwait. The four-day ground war was fought in a conventional matter against a defined opponent. On the other hand, the 1992-1993 mission in Somalia started out as a humanitarian operation during the presidency of George $\mathrm{H}$. W. Bush and ended as a failed military venture against a warlord during Bill Clinton's presidency, costing the lives of 18 American troops and prompting the resignation of Defense Secretary Les Aspin. Then there were the UN/NATO air missions against Serbia in Bosnia and Kosovo, of which American power prevented genocide in the Balkans.

On the international front, the US led the push to renew the Nuclear Nonproliferation Treaty and the Chemical Weapons Convention, which were approved in 1995 and 1997, respectively.

However, the 1990s also represented a regrowth of international terrorism. Among the most formative groups was al Qaeda, which gained a presence in dozens of nations and did not hide its intention to attack American interests. The first significant attack by that group against the US came in February 1993, when a truck bomb was detonated below the North Tower of the World Trade Center, killing six persons and injuring more than one thousand. One of the perpetrators had training by al Qaeda and part of the mission was financed by that organization. Though there were claims of Iraqi involvement in the 1993 World Trade Center bombing, no hard evidence was ever established of culpability. Six co-conspirators were caught, convicted, and sentenced to 240 years each. The November 1995 bombing of the military training center in Riyadh, Saudi Arabia killed seven, including five Americans. Four Saudi citizens with links to al Qaeda were caught, convicted, and beheaded for that attack.

When global pariah Osama Bin Laden was kicked out of Sudan with help from the US in 1996, he joined Egyptian terrorist Ayman al-Zawahiri and others as members of al Qaeda in Afghanistan. That group planned several attacks against Americans. In August 1998, al Qaeda operatives bombed US embassies in Nairobi, Kenya and Dar es Salaam, Tanzania, killing 200 and injuring 500. In response, the Clinton White House ordered retaliatory strikes against terrorist sanctuaries in Afghanistan and Sudan. After attempting to damage a US warship in January 2000, al Qaeda personnel succeeded in doing so in October of that year. A suicide bombing against the guided missile destroyer USS Cole left 17 Americans dead and 39 injured. There is certainly evidence that American authorities targeted Osama bin Laden before the September 11 attacks. For instance, the CIA located bin Laden at a camp in Afghanistan in 1998 but a cruise missile strike was rejected. Six months into the presidency of George W. Bush, the CIA tested a Predator drone on a replica of bin Laden's home, but did not proceed with an actual operation.

\section{September 11 and its Aftermath}

The devastating terrorist attacks against the United States undertaken on September 11, 2001 were planned directly by bin Laden and al Qaeda. The attacks, which used four hijacked planes as missiles, destroyed both World Trade Center towers, damaged the Pentagon, and killed nearly 3,000 persons.

Amid palpable fear of future attacks, Americans suffered a shock to their collective security. Airports were closed, Wall Street ceased trading, and Congress was evacuated on multiple occasions. The mailing of anthrax spores to government and media personnel and the crash of a civilian airliner in Queens only two months after September 11 only added to the sense of vulnerability. The domestic response to the September 11 attacks was 
highlighted by passage of the Patriot Act in October 2001. The measure furnished law enforcement with sweeping new powers to conduct searches, monitor financial transactions, and deport individuals suspected of terrorist ties. Further, the creation of the Department of Homeland Security in 2002 combined more than 20 separate agencies into a single cabinet department of 170,000 employees. Among the tasks assigned to this department were information sharing, screening of airline passengers, review of visa applications, and establishment of a suspicious activity reporting initiative. Likewise in 2002, the president and Congress approved the formation of the National Commission on Terrorist Attacks Upon the United

States, aka the 9/11 Commission. That group released its report in July 2004, and by the next year one key recommendation was implemented: Appointment of a Director of National Intelligence (DNI) to coordinate sharing of information among the plethora of agencies which comprise the intelligence community. The military response to the $9 / 11$ attacks was prolonged and expansive. After determining that al Qaeda masterminded the travesty, President George W. Bush demanded that the Taliban leaders in Afghanistan hand over Osama bin Laden. When they refused, the US launched Operation Enduring Freedom and quickly toppled the Taliban government. America joined the International Security Assistance Force (ISAF) in December 2001, which had been set up by the United Nations Security Council to oversee military operations in Afghanistan. In 2003, NATO took control of the ISAF, although American troops operated under direct American command.

In 2002, the George W. Bush administration announced a new defense doctrine in a document titled The National Security Strategy of the United States. This doctrine essentially codified the practice of preemption - attacking a perceived enemy before that opponent has the opportunity to hurt American interests. The Bush White House's declaration that certain nations form an "Axis of Evil" through combining terrorist activities with possession of weapons of mass destruction gave the aforementioned administration the pretext to invade Iraq in March 2003, fostering simultaneous conflicts in Afghanistan and Iraq. By now, the undeclared war against al Qaeda and global terrorism was paying dividends in one way: capture of a large number of non-soldiers, or enemy combatants. The strategy for incarcerating and interrogating them began a year earlier.

\section{Dealing With Detention}

The detention camp at Guantanamo Bay, Cuba is a military prison located within the US naval base there. It opened on January 11, 2002. According to then-Secretary Donald Rumsfeld, the prison camp would function to detain, interrogate, and prosecute dangerous persons who were captured as part of the war on terror.

The Guantanamo Bay military prison—-known as GITMO - has housed a total 779 detainees to date. During the George W. Bush administration, the total number at the facility peaked at 660 in 2004. Though almost one-third of those enemy combatants held at GITMO were from Afghanistan, a large number likewise had nationality from Saudi Arabia, Yemen, and Pakistan. There was even one American among the almost 100 caught in Afghanistan who spent time at GITMO.

\section{A Legal Defense of GITMO and Interrogation Methods}

The George W. Bush administration set about to justify the holding of "enemy aliens" as a pretext for opening GITMO. A December 28, 2001 memorandum from Deputy Attorneys General Patrick Philbin and John Yoo to Department of Defense General Counsel William Haynes carefully laid out the case for denying jurisdiction to entertain a habeas petition. A January 25, 2002 memorandum from White House Counsel Alberto Gonzales to President Bush made the argument that the Taliban and al Qaeda should be regarded as 
outside the protection of the Geneva Convention, a position questioned by Secretary of State Colin Powell but ultimately approved.

In a July 2002 meeting at the CIA, agency staff heard a report from psychologists who previously trained US military personnel in surviving capture and torture. Several of these harsh interrogation techniques-including waterboarding, sleep deprivation, and stress positions-would soon be employed at GITMO, according to a 2014 New York Times article.

Between August 2002 and April 2003, Bush administration personnel distributed a series of memorandum which discussed and ultimately sanctioned brutal interrogation methods against detainees. An August 2002 memo composed by the Office of Legal Counsel in the Justice Department offered a rationale for using torture against al Qaeda operatives. In a March 2003 memo, a legal task force at the Department of Defense claimed that President Bush's authority as commander-in-chief permitted him to utilize any interrogation technique which protects national security, thus exempting him from both international treaties and federal statutes prohibiting torture. Finally, Secretary of Defense Donald Rumsfeld's April 2003 memo codified 24 approved interrogation methods, which were labeled as "counter-resistance techniques in the War on Terrorism."

\section{From Gitmo to Secret Prisons to Iraq}

According to the 2014 Senate Intelligence Report's analysis of CIA torture use during the George W. Bush administration, a secret order was signed by President Bush on September 17, 2001— just six days after the terrorist attacks against America - which furnished the CIA with the authority to capture and imprison al Qaeda members. But because the order did not specify a specific location for such prisons, the CIA was left to fill in the blanks. While there is evidence that the CIA wanted to house detainees at US military installations overseas and furnish captives with full legal rights, there is likewise the reality of what actually transpired: creation of a series of secret prisons or "black sites" in friendly foreign countries where the CIA took control of interrogation methods. Eventually, black sites were set up in Afghanistan, Poland, Thailand, Romania, Lithuania.

When the US invaded Iraq in March 2003, Saddam Hussein's regime was quickly toppled. But a short-term occupation became long-term nation-building as an insurrection kept American forces busy. It was not long before the CIA started using the torture methods on detainees at a prison there, Abu Ghraib.

\section{The Fallout}

\section{Torture is Torture}

Whatever legal shenanigans were used to justify extreme methods of questioning detainees, the techniques adopted by the CIA were not only deemed torture, but war crimes by groups such as the United Nations and Amnesty International. In Iraq at Abu Ghraib, detainees "under American control were raped, beaten, shocked, stripped, starved of food and sleep, hung by their wrists, threatened with death, and in at least one case, murdered", according to a February 2015 New York Times article.

At the black sites in Afghanistan and elsewhere, the CIA held a total of 119 detainees, of whom 26 were subsequently determined to have been held in error, according to the 2014 Senate Intelligence Report. Of those who remained at these prisons, there is documented evidence of techniques against captives that included 66 hours of standing sleep deprivation in one case and the waterboarding of 9/11 planner Khalid Shaikh Mohammed 183 times. The Thailand facility closed as early as December 2002. Documents in the Senate 
report indicate that the Romanian prison closed in 2005 shortly after a Washington Post article exposed details about the interrogation program there. The black site in Lithuania was shuttered in 2006 after both a local hospital and Pentagon officials refused to help a CIA detainee in medical distress. The last detention facility in Afghanistan was not transferred to local control until December 2014.

At GITMO, the same brutal techniques against detainees were used. Former detainees gave accounts of abuse and torture at the facility. In 2005, Amnesty International called GITMO "the Gulag of our times". In 2006, the United Nations called for the prison to close. In a 2015 publication, current GITMO detainee Mohamedou Ould Shahi recounts how he was isolated, beaten, tortured, and sexually abused during the early years of his incarceration there. Finally, information about most GITMO captives held between 2002 and 2008 found in classified Detainee Assessment Briefs were released by WikiLeaks. Referred to as "The Guantanamo Files" the memos indicate each detainee's level of risk and value, which in turn determined the severity of questioning used. The aforementioned files also document that seven persons died while being held at GITMO during the George W. Bush presidency.

\section{The Courts Weigh in}

From the outset of the response to the September 11, 2001 terrorist attacks, the George W. Bush administration sought to avoid legal consequences for decisions made pertaining to the detention of captured personnel. The result was a series of after-the-fact reactions to court rulings.

In November 2001, President Bush signed an order classifying captured terrorists as enemy combatants who would be tried by military tribunals. But only eight detainees ever subjected to military tribunals there have been convicted. The lack of military trials and rights not afforded in them when held led some detainees to seek redress from the courts.

In 2004, two US Supreme Court rulings chipped away at the Bush administration's strategy of arguing that the courts lacked jurisdiction and authority to scrutinize the chief executive's detention policy in fighting terror. In Rasul v. Bush, the Court backed the right of GITMO detainees from Australia and Kuwait to file suit for habeas corpus, counsel, and an independent tribunal. Another decision in 2004-in Hamdi v. Rumsfeld-is often described as a win for the Bush administration since it supported labeling an American terrorist as an enemy combatant and allowed his detention. But that ruling likewise afforded the petitioner the right to counsel and to contest the basis of his detention before an independent tribunal.

Following the dual decisions by the US Supreme Court, the Defense Department created the Combatant Status Review Tribunal process at GITMO, which began in July 2004. In December 2005, the Congress passed the Detainee Treatment Act in response to the legal issues raised by treatment of prisoners at GITMO. Among its provisions was an explicit prohibition against "cruel, inhuman, or degrading treatment or punishment" which was strongly supported by US Senator John McCain (R-AZ), a Vietnam War POW who was repeatedly subjected to torture while in captivity. The act, signed into law by President Bush, also included acknowledgment of the CSRT mechanism.

However, the US Supreme Court ruled in the 2006 Hamdan v. Rumsfeld case that the Combatant Status Review Tribunal process violated both the Uniform Code of Military Justice and Geneva Convention agreements. Once again, the Bush administration reacted to events by seeking to limit the rights of detainees at GITMO. After the Hamdan ruling, Congress passed the Military Commissions Act of 2006 as a replacement for the disgraced CSRT. The latter act forbade those detainees classified as enemy combatants from filing habeas 
corpus petitions to federal courts. In 2008, the US Supreme Court ruled in the Boumediene v. Bush and Al Odah v. US cases that the section of the 2006 Military Commissions Act which restricted detainee remedies was unconstitutional and that those being held at GITMO prisoners had the right to initiate habeas corpus challenges in federal courts.

\section{Obama White House Reverses Course on Torture}

Just two days into his term as America's 45th chief executive, President Barack Obama issued an executive order forbidding the use of torture and promulgating rules for lawful interrogations. Two months later, he released four classified CIA documents about torture practices, which offered a peek into what would be exposed by the release of the 2014 Senate Select Intelligence Committee report. There would not be near the uproar in 2009 as that which transpired in 2014.

The goal of closing GITMO, which was also part of President Obama's early executive order, has proven much harder to accomplish. Originally a 2008 campaign promise, Obama repeated the aspiration during his reelection campaign in 2012, during his 2015 State of the Union speech, and most recently the February 23, 2016 plan released by the White House for GITMO's closing speech. Although the Obama administration had a window in 2009 for bipartisan backing for closing the GITMO detention facility, it dissipated and was replaced with partisan bickering. While not all of this was President Obama's fault, he inflamed the controversy by repeatedly threatening to act on his own to close the facility. Combined with his generally poor relations with Congress, this only led to more opposition, even within his own party.

The elements of the Obama White House's 2016 plan for shuttering the GITMO detention facility included continuing to transfer those detainees already cleared back to their nation of origin; accelerating periodic review of detainee status; utilizing all legal tools to facilitate detainee hearings and sentencing; and securing one or more locations within the US of those detainees deemed high-security risks.

Approximately 61 detainees remain at GITMO presently, and although about one-third are slated for transfer the various destinations soon, the remaining group's fate is uncertain. With control of Congress in Republican hands, it appears that any scenario whereby GITMO prisoners would be moved to prisons within the US remains remote. Further, the instability presently happening in Yemen and elsewhere will probably slow transfer of detainees back to that nation.

With the renewal of violence in Iraq, with a supplemental military presence still in Afghanistan, and with the current threat posed by ISIS, opportunities to capture enemy combatants may increase instead of decrease, as much as President Obama wants to lessen America's military adventures abroad.

\section{Tribulations of US Detention Policy for Bush and Obama}

One thorn in the side of the both the Bush and Obama administrations is the revelation that many former GITMO detainees have rejoined terrorist networks. A study during the George W. Bush presidency showed that as many as $30 \%$ of the 532 detainees released from GITMO renewed terrorist activities. Another study focusing on the Obama aministration's record with recidivism confirmed that at least 23 released detaines rejoined terrorist groups over the last two years. In the vast majority of cases, those persons were subjected to minimal judicial proceedings while at GITMO, which ironically could have legitimized their continued incarceration.

The Bush team chose GITMO over trying captured terrorists in federal criminal courts within the US, as that only occurred in three instances. When the Obama White House announced its intention to hold a criminal 
trial of one of the detainees in New York, the blowback was so intense that similar ideas were scrapped. Meanwhile, the military commission procedure has been an utter failure for both President Bush and President Obama. For one point, a US Court of Appeals ruling recently rejected the use of such bodies for non-war crime cases. Further, only eight of 779 total prisoners at GITMO have been convicted by a military commission.

The cost of holding a single prisoner for a year at GITMO is $\$ 3.3$ million per year, or about 40 times the cost of housing a prisoner at a maximum security prison within the US, according to a January 2015 Washington Post article. While the Bush White House may have correctly gauged that public opinion did not support moving GITMO detainees to the mainland, the price tag of keeping them locked up indefinitely together with the cost of two active wars drained the pocketbooks and patience of Americans. President Obama cited GITMO's cost per detainee as a rationale for accelerating the closing of the facility in his February 2016 announcement.

In a number of other ways, the rhetoric of the Barack Obama administration pertaining to the GITMO detention facility has been inconsistent with actual policies, causing friction and confusion. For example, against the claim that GITMO has been used as a recruitment device for terrorist networks, the Wall Street Journal conducted an extensive study of video, print, and voice sources and found very little direct evidence indicating that GITMO has been depicted in such a manner.

Moreover, the Obama White House has repeated the policy of the George W. Bush administration to oppose every detainee petition for habeas corpus, even after the 2008 Supreme Court holdings in Boumediene v. Bush and Al Odah v. US The effect of this is twofold: it denies even the most basic right to those Captured, but likewise delays the process of prosecuting or transferring detainees.

In certain ways, the Obama administration even seems to be softening its position on torture. First, while President Obama authorized the release of 198 pictures of detainee abuse from a decade ago, the White House has simultaneously forbid release of another 1,800 such pictures, defying a plethora of Freedome-ofInformation requests. Second, even after the American Psychological Association reversed its policy on allowing pyschologists to participate in GITMO interrogations, the Pentagon recently asked the APA to reconsider its ban. Third, just as the Obama team has refused to prosecute those involved in torture and other unseemly policies associated with the fight against terror, so it has failed to assist Americans arrested for such behavior. For instance, former CIA agent Sabrina de Sousa recently sued the US State Department and CIA following here conviction in Portugal for black site activities; she is awaiting extradition to Italy.

\section{Commentary}

In evaluating the detention policy practiced by the George W. Bush administration, one first has to view actions in that area in comparison. From the vantage point of the immediate aftermath of the September 11 attacks, the use of cruel and inhuman methods of exacting information from captives, the creation of secret prisons overseas run by the CIA, the effort to avoid court scrutiny over facets of the detention program are all traits of an overall reaction to a national emergency. But combined with domestic laws which challenged Americans' privacy and disturbing profiling trends, the aforementioned characteristics are part of a familiar long-term pattern by US authorities when confronted with similar conditions: overreaction on the side of safety. From the anti-speech laws enacted during America's participation in World War I to internment of Americans of Japanese heritage during World War II to dispatching National Guard troops against protesters during the Vietnam War, the tendency to adopt extreme measures in times of fear and uncertainly points to America's 
inherent political reflex to guard its institutions against dis-equilibrium. What is more disturbing is the normalization of war, and therefore crisis governance in which personnel tolerate actions which may be immoral, illegal, or stupid. But make no mistake, despite pockets of resistance, Congress and the American people were "all in" with the Bush detention program and remain so according to January 2015 polls which show that a majority of Americans support the CIA tactics utilized in the Bush years to root out terrorists.

Of course, any judgment of the detention policies of the George W. Bush and Barack Obama administrations must include a determination of the program's success. In this case, we can define success as extraction of information which proved effective in the pursuit of al Qaeda leaders and other terrorists. According to former CIA acting director John McLaughlin, the agency's detention and interrogation programs were responsible in one way or another for all of the following: (1) finding Osama bin Laden; (2) capturing 9/11 mastermind Khalid Sheikh Mohammed; (3) capturing Southeastern Asian terrorist leader Riduan Isamuddin; (4) disrupting a "second wave" plot on the West Coast; and (5) disrupting plots to bomb Karachi hotels.

Alternately, present CIA director John Brennan was more ambiguous in responding to the Senate Intelligence Committee report about the value of the spy agency's interrogation tactics. He stated that the use of unauthorized techniques went "out of bounds" and were "regrettable". While defending harsh tactics for helping to find Osama bin Laden, Brennan nonetheless opined that was "unknown and unknowable" whether the brutal techniques yielded information which could have been acquired in any other way. What is known is that Osama bin Laden was caught and killed on Barack Obama's watch, not that of George W. Bush.

Ultimately, the verdict of how US detention policy should be regarded is subject to the rule of law and to fundamental values which define the American psyche. Torture is inimical to not only laws which the US has trumpeted, but to international standards which America has supported. If the use of such tactics becomes an end in itself, then we are no better than the ISIS thugs who behead helpless hostages in an orgy of violence. The US government has chosen not to become a member of the International Criminal Court largely out of fear that our troops may be subject to war crime tribunals. Not coincidentally, that is exactly what Spanish authorities allege in an outstanding warrant against US personnel for the torture program. Meanwhile, close allies like Britain have acknowledged their role in assisting American torture of detainees and have begun reparations for affected persons. Conversely, both President Bush and Vice President Dick Cheney strongly defended the interrogation methods used against captured terrorists while in office and in their respective memoirs.

\section{Conclusions}

That the detention policy of the George W. Bush presidency was a by-product of the terrorist attacks against America on September 11, 2001 means that if the latter event is still relevant in our approach to military and national security policy, so is GITMO. Indeed, we have witnessed a flurry of recent news surrounding 9/11, from questions about whether more Saudi citizens were involved in the attacks, to the controversy surrounding the WTC museum gift shop, to health issues impacting those first responders to the attacks. President Barack Obama's immediate action to prohibit torture as a way to interrogate captives connoted a recognition that some universal precepts such as human dignity should not be open for debate.

Yet, the Obama White House has failed to close the GITMO prison and its accompanying symbols like the orange jumpsuits. In many ways the Obama pursuit of terrorists has been more aggressive than that of President George W. Bush, particularly in the use of drones to kill terrorist conspirators. It is easier to take the bad guys 
out quickly than to keep them alive in order to extract information, especially when its benefits for capturing terrorists remains in doubt.

\section{References}

Aolain, F. N., \& Gross, O. (Eds.) (2013). Guantanamo and beyond: Exceptional courts and military commissions in comparative perspective. New York: Cambridge University Press.

Baker, T. E., \& John F. Stack, Jr., (Eds.) (2006). At war with civil rights and civil liberties. Lanham, MD: Rowman and Littlefield Publishers.

Barnet, R. J. (1990). The rockets' red glare: When America goes to war-The presidents and the people. New York: Simon and Schuster.

Barnett, R. E. (2004). Restoring the lost constitution: The presumption of liberty. Princeton: Princeton University Press.

Berkowitz, P. (Ed.). (2005). Terrorism, the laws of war, and the constitution: Debating the enemy combatant cases. Stanford, CA: Hoover Institution Press.

Blum, G., \& Heymann, P. B. (2010). Laws, outlaws, and terrorists: Lessons from the war on terrorism. Cambridge, MA: MIT Press.

Brown, C. (2003). Lost liberties: Ashcroft and the assault on personal freedom. New York: The New Press.

Bush, G. W. (2010). Decision points. New York: Crown Publishers.

Campbell, C., \& Rockman, B. A. (Eds.) (2004). The George W. Bush presidency: Appraisals and prospects. Washington: CQ Press.

Carey, H. F. (2012). Reaping what you sow: A comparative examination of torture in the United States, France, Argentina, and Israel. Santa Barbara: Praeger.

Cheney, D. (2011). In my time: A personal and political memoir. New York: Threshold Editions.

Cole, D., \& Dempsey, J. X. (2002). Terrorism and the Constitution: Sacrificing civil liberties in the name of national security. New York: The New Press.

Del Rosso, J. (2015). Talking about torture: How political discourse shapes the debate. New York: Columbia University Press.

Draper, R. (2007). Dead certain: The presidency of George W. Bush. New York: Free Press.

Fisher, L. (1995). Presidential war power. Lawrence: University Press of Kansas.

Fisher, L. (2003). Nazi Saboteurs on trial: A military tribunal and American law. Lawrence: University Press of Kansas.

Fisher, L. (2005). Military tribunals and Presidential power: American revolution to the war on terrorism. Lawrence; University Press of Kansas.

Fortier, J. C., \& Ornstein, N. J. (Eds.) (2007). Second-term blues: How George W. Bush has governed. Washington, DC: American Enterprise Institute and Brookings Institution Press.

Gates, R. M. (2014). Duty: Memoirs of a secretary at war. New York: Alfred A. Knopf.

Globalizing Torture: CIA Detention and Extraordinary Rendition. (2013). New York: Open Society Foundations.

Greenberg, K. (2009). The least worst place: Guantanamo's first 100 days. New York: Oxford University Press.

Greenstein, F. I. (Ed.). (2003). The George W. Bush presidency: An early assessment. Baltimore: Johns Hopkins UniversityPress.

Greenwald, G. (2007). A tragic legacy: How a good vs. evil mentality destroyed the Bush presidency. New York: Crown Publishers.

Gregg II, G. L., \& Rozell, M. (Eds.) (2004). Considering the Bush presidency. New York: Oxford University Press.

Hallet, B. (2012). Declaring war: Congress, the President, and what the constitution does not say. New York: Cambridge University Press.

Harlowe, B. (Ed.). (2015). Rebuttal: The CIA responds to the Senate Intelligence Committee's Study of Its Detention and Interrogation Program. Annapolis: Naval Institute Press.

Hayden, M. V. (2016). Playing to the edge: American intelligence in the age of terror. New York: Penguin Press.

Hentoff, N. (2003). The war on the Bill of Rights and the gathering resistance. New York: Seven Stories Press.

Heymann, P. B. (2003). Terrorism, freedom, and security: Winning without war. Cambridge, MA: MIT Press.

Hoff, S. B. (2003, August 20). Bush's Military Tribunals are Un-American. Delaware State News.

Hoff, S. B. (2005). Torture not in line with American values. Delaware State News, December 17.

Hoff, S. B. (2011, September 8). 9/11 and US response to the perceived threat. WDDE.org (online).

Hoff, S. B. (2014). Releasing "Torture Files" right step in restoring honor. Wilmington News Journal, December 10. 
Hoff, S. B. (2015, January 7). What US won during war in Afghanistan. Delaware State News.

Howell, W. G., Saul P. J., \& Rogowski, J. C. (2013). The Wartime President: Executive influence and the nationalizing politics of threat. Chicago: University of Chicago Press.

Inquiry Into the Treatment of Detainees in US Custody. (2008). Washington, DC: US Senate Committee on Armed Services Report, November 20.

Inter-American Commission on Human Rights. (2015). Toward the closure of Guantanamo. Washington, DC: Organization of American States.

Irons, P. (2005). War powers: How the imperial presidency hijacked the constitution. New York: Metropolitan Books.

Jaffer, J., \& Singh, A. (2007). Administration of torture: A documentary record from Washington to Abu Ghraib and beyond. New York: Columbia University Press.

Javits, J. (1973). Who makes war: The President versus congress. New York: William Morrow and Company.

Jervis, R. (2015). The torture blame game. Foreign Affairs, 94(3), 120-127.

Keyes, E. (1991). Undeclared war: Twilight zone of constitutional power. University Park: Pennsylvania State University Press.

Kimstim, I. (2010). DVD: Torture made in the USA. Brooklyn, NY.

Klaidman, D. (2012). Kill or capture: The war on terror and the soul of the Obama presidency. Boston: Houghton Mifflin Harcourt.

Lehman, J. (1992). Making war: The 200-year old battle between the President and Congress over how America goes to war. New York: Charles Scribner's Sons.

Leone, R. C., \& Greg Anrig, Jr. (Eds.). (2003). The war on our freedoms: Civil liberties in age of terrorism. New York: Century Foundation.

Magic Play Entertainment/Yorkshire Television. (2009). DVD: GITMO: The True Story.

Margulies, J. (2006). Guantanamo and the abuse of presidential power. New York: Simon and Schuster.

McCoy, A. W. (2006). A question of torture: CIA interrogation, from the Cold War to the war on terror. New York: Owl Books.

Moyar, M. (2015). Strategic failure: How President Obama's drone warfare, defense cuts, and military Amateurism have imperiled America. New York: Threshold Editions/Simon and Schuster.

National Geographic Channel. (2009). DVD: Inside Guantanamo.

O'Brien, D. M. (2008). Constitutional law and politics: Struggles for power and government accountability. New York: W.W. Norton and Company.

Pallitto, R. M., \& Weaver, W. G. (2007). Presidential secrecy and the law. Baltimore: The Johns Hopkins University Press.

Pfiffner, J. P. (2008). Power play: The Bush presidency and the constitution. Washington, DC: Brookings Institution Press.

Pious, R. M. (2006). The war on terrorism and the rule of law. Los Angeles, CA: Roxbury Publishing Company.

Plan for Closing the Guantanamo Bay Detention Facility. (2016). Washington: White House.gov, February 23.

Posner, R. A. (2006). Not a suicide pact: The Constitution in a time of national emergency. New York: Oxford University Press.

Rehnquist, W. H. (1998). All the laws but one: Civil liberties in wartime. New York: Vintage Books.

Report on CIA Interrogation Program. (2014). Washington, DC: US Senate Select Committee on Intelligence.

Rodriguez, Jr., \& Jose A. (2012). Hard measures: How aggressive CIA actions after 9/11 saved American lives. New York: Threshold Editions/Simon and Schuster.

Roth, K., \& Worden, M. (Eds.). (2005). Torture: Does it make us safer? Is it ever ok?A human rights perspective. New York: The New Press.

Sammon, B. (2002). Fighting back: The war on terrorism from inside the Bush White House. Washington, DC: Regnery Publishing.

Sands, P. (2008). Torture team: Rumsfeld's memo and the betrayal of American values. New York: Palgrave McMillan.

Sanger, D. E. (2012). Confront and conceal: Obama's secret wars and surprising use of American power. New York: Crown Publishers.

Sarat, A. (Ed.). (2014). Knowing the suffering of others: Legal perspectives on pain and its meaning. Tuscaloosa: University of Alabama Press.

Schlesinger, Jr., \& Arthur, M. (2005). War and the American presidency. New York: W.W. Norton and Company.

Schulhofer, S. J. (2002). The enemy within: Intelligence gathering, law enforcement, and civil liberties in the wake of September 11. New York: Century Foundation Press.

Sidley Austin LLP. (2015). Report to the Special Committee of the Board of Directors of the American Psychological Association Relating to APA Ethical Guidelines, National Security Interrogations, and Torture. Chicago, IL, July 2. 
Smith, C. S. (2007). Eight o'clock ferry to the windward side: Seeking justice in Guantanamo Bay. New York: Nation Books. Stelloh, T. (2016, August 15). Fifteen guantanamo bay detainees released to United Arab Emirates. NBCNews.com.

Stern, Gary M., \& Halperin, M. H. (Eds.). (1994). The US Constitution and the power to go to war. Westport, CT; Greenwood Press.

Strassser, S. (Ed.). (2004). The Abu Ghraib investigations. New York: Public Affairs Reports.

Suskind, R. (2006). The one percent doctrine: Deep inside America's pursuit of its enemies since 9/11. New York: Simon and Schuster.

The 9/11 Commission Report. (2004). New York: W.W. Norton and Company.

The Guantanamo Files. (2014). WikiLeaks.org, accessed June 2.

The Report of the Constitution Project's Task Force on Detainee Treatment. (2013). Washington, DC: The Constitution Project.

Tushnet, M. (Ed.). (2005). The Constitution in wartime: Beyond alarmism and complacency. Durham, NC: Duke University Press.

Waldron, J. (2010). Torture, terror, and trade-offs: Philosophy for the White House. New York: Oxford University Press.

Washington Media Associates. (2008). DVD: Torturing democracy.

WGBH Educational Foundation. (2015). PBS Frontline DVD: Secrets, politics, and torture.

Witness.Org. (2006). DVD: Outlawed: Extraordinary rendition, torture, and disappearances in the "war on terror".

Wormuth, F. D., \& Firmage, E. B. (1989). To chain the dog of war: The war powers of congress in history and law. Urbana: University of Illinois Press.

Woods, Jr., Thomas, E., \& Kevin R.C. Gutzman. (2008). Who killed the constitution?: The fate of American Liberty from World War I to George W. Bush. New York: Crown Forum.

Woodward, B. (2010). Obama's wars. New York: Simon and Schuster.

Woodward, B. (2008). The war within: A secret White House History, 2006-2008. New York: Simon and Schuster.

Zelizer, J. E. (2010). The presidency of George W. Bush: A first historical assessment. Princeton: Princeton University Press. 